\title{
DEVELOPMENT OF LOW-STATUS ROMA STUDENTS IN A HETEROGENEOUS GROUP OF STUDENTS IN TERMS OF KNOWLEDGE AND SOCIALIZATION
}

\author{
Author: \\ Emese K. Nagy (PhD) \\ University of Eszterházy Károly
}

Szerző e-mail címe:

k.nagy.emese@gmail.com
Reviewers:

Hanák Zsuzsanna (PhD, Habil.)

University of Eszterházy Károly

Révész László (PhD)

University of Eszterházy Károly

...and other two reviewers

\begin{abstract}
Absztrakt
ALACSONY STÁTUSÚ ROMA TANULÓK FEJLESZTÉSE HETEROGÉN TANULÓCSOPORTBAN A TUDÁS ÉS A SZOCIALIZACIÓ SZEMPONTJÁBÓL

Jelen tanulmány a komplex oktatási programot (angolul: Coplex Instuction Program) és annak hatását mutatja be az alacsony státusú roma tanulók osztálytermi teljesítményére, beszélgetésük gyakoriságára és feladathoz kapcsolódó tantermi aktivitásukra.
\end{abstract}

Kulcsszavak: Komplex Instrukciós Program, roma, oktatás

Diszciplina: pedagógia

\begin{abstract}
Abstarct
The present study shows on the Complex Instruction Program (in Hungarian: Komplex Instrukciós Program - KIP) and its impact on low-status roma student's classroom performance, the frequency of their talk and their task-related classroom activity.
\end{abstract}

Keywords: Complex Intsruction Program, roma, education

Discipline: pedagogy

K. Nagy, Emese (2020): Development of Low-status Roma Students in a Heterogeneous Group of Students in Terms of Knowledge and Socialization. OxIPO interdiszciplináris tudományos folyóirat, 2020/2, 21-31. doi: 10.35405/OXIPO.2020.2.21 
Due to the diversity of cultural and social backgrounds, there is a high degree of knowledge divergence in the student population. The question is how to respond to this diversity and challenge with a high-quality education. It is characteristic of successful education and teaching that individual treatment and differentiation are present to help both gifted and children needing catch-up. All children should receive education and training appropriate to their abilities, which is of particular importance with regards to Roma children. Below, we present how it is possible to consider the Complex Instruction Program, a component of the Hejökeresztúr Model, based on a special cooperative process pedagogically, psychologically, and sociologically as a part of an educational system well-considered and consciously structured with respect to both theory and practice. The question is why the program is suitable for the education and teaching of low-status Roma students, especially those who are lagging behind in terms of school success.

\section{Complex Instruction Program}

The Complex Instruction Program (KIP) is a teaching method that allows teachers to organize high-level group work in classes where the difference in students' knowledge and expression moves within broad limits, and as a result of classroom work, it slows down or prevents students from disadvantaged backgrounds, mainly Roma ones from falling behind and promotes that of the more talented ones. The aim of the method is to raise the level of knowledge of every child and to enable them to experience classroom success. The complexity of the method means that the activities needed to develop the personality and key competence of learners are combined. In education, the cognitive, moral, and affective components of education and teaching are equally important, that is, none of the goals of scientific-intellectual, social-citizenship, or personality development are prioritized. The aim of the program is to use a group work-based approach that gives students real-life and experiential personal experiences in classroom work. The program is primarily suited for creating equal opportunities for students from disadvantaged backgrounds, especially Roma ones in classroom work because ranking problems in the class-room become recognizable and manage-able. This is an essential aspect in the case of Roma students as experience has shown, they are overrepresented in the bottom third of a heterogeneous class.

A further reason for using the program is that during group work in heterogeneous classes, it is possible to prepare students for norms of collaboration through the use of a special instructional procedure. It is also possible to develop the skills that are hidden beneath the surface by using a wide variety of 
different curriculum materials that activate multiple skills.

The expected impact of the program is to contribute to the development of student communication, especially in terms of talk frequency and task discussion with respect to all students, especially low-status Roma students. Our basic idea is that the more students talk and the more they act, the more they learn. This requires appropriate openended tasks that need innovative thinking. (Cohen \& Lotan, 2014; K. Nagy 2012, 2015; K. Nagy \& Révész, 2019).

\section{Impact of status}

\section{on students' classroom performance}

Before formulating our thoughts, we feel the need to clarify the concept of status.

Status is defined very generally as the value of a given position in any hierarchy (formal or informal). According to Reményi (1997), statuses can always be interpreted dyadically, in relation to another person, i.e. Ego always compares himself/herself to Alter. An informal hierarchy, which can be found inside and outside an organization, is defined by an almost infinite number of human characteristic features, dimensions, attributes, and the community's value system determines the relative order of importance of these attributes (although they do not have an equal say in the matter) in such a way that the members of the community assign a value to these attributes. For example, wealth, health, knowledge, physique or strength, taste, expertise, "connections", authority, or even belonging to a religious, ethnic group, - in our case to the Roma,- or a professional group all define a certain informal hierarchy.

Ferenc Mérei (2001) believes that the individual is born into society, within this into a family, one of the social layers, which marks his or her starting status in life. However, he also thinks that the individual will enter into society when "turnarounds" happen in his or her later life, such as going to school, choosing a job, or becoming a member of an organization. He also points out the important feature that an individual becomes not only a participant, a passive recipient but also a shaper of his or her environment.

Status is a rank order and accepted stratification of society in which everyone feels that it is better to achieve a higher rank than a lower one. Students who are excluded from the community for social reasons or those who are lagging behind in learning are often reluctant to participate in joint work; as a result, they, however, learn less than those who are more active. If students are not equally involved in classroom work, their progress in learning will be uneven. Students at the top of the class have more influence on group decision making, are asked more often for help, and have more 
opportunities to express their opinions than those at the bottom of the rank, whose opinions are usually ignored, which is a manifestation of a status problem (Cohen, 1994).

We suppose that the child's place in class rank is primarily determined by school performance (academic performance, sports performance, musical talent, etc.), which is influenced by belonging to a particular social layer, social status (a potential cause of disadvantage - Cohen-Lotan, 2014).

Below, we present how status, the place occupied in the classroom, in the group, influences students' classroom performance. We would like to point out that although disadvantage does not mean that students in this group are sole of Roma origin, it is typical that the proportion of Roma students is high among students from disadvantaged backgrounds.

In our examinations, we measured the classroom performance of 48 students from two schools organized in accordance with the Complex Instruction Program. We began the measurement by summarizing the responses to the sociometric questionnaire, which helped us to establish a hierarchical order between students and to distinguish between low- and high-status students. High- and low-status students were selected for measurement on the basis of a summary of sociometric survey sheets.

To measure lesson work, we used an Individual Student Observation Sheet (see appendix) to record the task-related activity of low- and high-status students (The work of the 48 low and high-status children was monitored for three minutes. The minutes were divided into additional 30-second intervals, so if a child talked related to the task for more than 30 seconds, he or she received several entries during the observation. If a student did not talk related to the task but related to his or her role and then returned to the task within 30 seconds, he or she could receive more than one signal per interval. One conversational or behavioral manifestation meant one opportunity as long as the child did not interrupt it or switch activities).

\section{Impact of status on the frequency of talk}

By examining the relationship between status and talk frequency, we sought to determine whether there is a difference in the rate of task-related talk of high-status children compared to that of low-status ones during classroom work.

When examining task-related talk activity, we made a comparison between 48 observed children taught in accordance with the program and the control group (frontal classroom teaching) in the case of both low- and high-status students.

On the basis of our measurements, we conclude that there is a significant correlation between student status and 
frequency of task-related talk, which is justified by the following calculations: the average talk rate of low-status students among all observed students - in accordance with the program and traditional classroom activity - was 2.36 for 3 minutes, while that of high-status students was 3.8, showing a 1.61-fold difference.

During classroom observations based solely on group work, in accordance with the program, the talk rate of low-status students averaged 2.86 over the same interval, while that of high-status students was 4.95 , showing a 1.73.difference.

In the control group, the talk rate of low-status children over the same time period was 0.33 , while that of high-status children was 0.9 , so the difference was 2.72 fold (Figure 1).

Comparing the values, it can be seen that the talk rate of low-status students is lower in all comparisons than that of high-status ones, which results in higher status students having more opportunities for oral performance than low-status ones, and it is likely that higher frequency of talk gives students more opportunities for a task-related activity and, at the same time, for knowledge acquisition.

It is also noticeable that both low- and high-status students have the most opportunities for oral performance and developing their communication skills in the group work-based teaching method.

Figure 1: Students' talk frequency during various techniques for organizing classroom activities (by Author)

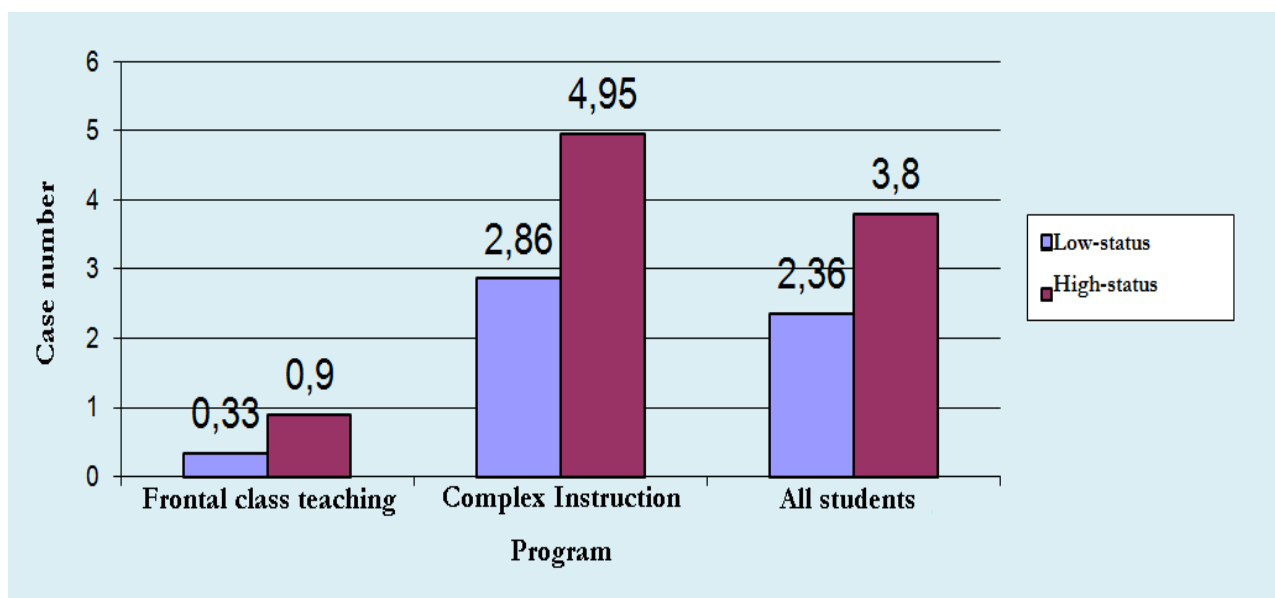


Noteworthy is the value obtained in the control classes performing traditional classroom activities, which indicates that traditional classroom work tends to be more favorable for high-status students to assert themselves and to perform well in class than for low-status ones, but the frequency of talk of both groups is lower than in group sessions. It could be said that the program reduces the difference between students with a different status, as in the case of group-based classroom organization, the talk rate of low-status students is on average 8.67 fold of that of the control group $(2.86 / 0.33)$ while this value is 5.5 fold (4.95/0.9) among highstatus children. However, the result obtained during the assumption must be treated with caution due to the low number of elements in the control group (frontal classroom teaching).

\section{Impact of status on students' task-related classroom activity}

When examining the relationship between status and student activity, we sought to determine whether group work according to the program influences the taskrelated class activity of low-status students compared to traditional frontal classwork.

When investigating active participation in the teaching process, we examined the mean of independent student work and peer work activities. In the case of both low- and high-status students observed, a comparison was made between the children taught in accordance with the program and the control group (frontal classroom teaching). On the basis of our measurements, in the case of low-status students participating in group work, the mean of activities is 1.73 for 3 minutes, while it is 0.08 in the control group.

The difference is 21.6-fold (1.73 / 0.08), where the significant discrepancy can be explained, on the one hand, by the difference in the way of how a lesson in the two teaching processes is organized and, on the other hand, - probably -, by the conscious teacher's activity that of the requirements of status treatment prioritizes collaboration between students (Figure 2).

In contrast, in the case of high-status children working in accordance with the program, the mean of participation is 2.32 while in the control group it is 0.23 , a difference of 9 fold $(2.32 / 0.23)$.

According to the results of the workbased lesson organization, the activity rate of low-status students is an average 21.6 fold of that of the control group, while among high-status children this value is 9 fold. As can be seen, the benefit of group work in the case of low-status students is manifested in the fact that it provides more opportunities for students to assert themselves than traditional classwork. 
Figure 2: Activity frequency of students from disadvantaged backgrounds and percentage distribution during classwork (by Author)

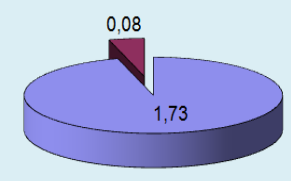

DGroup work ( $96 \%$ )

口Frontal classwork (4\%)

Comparing the two status groups, we can see that during the classroom observations in accordance with the program, the activity rate of low-status students is 1.73 on average, while that of high-status students is 2.32 , the difference being 0.59 fold (Figure 3).

Figure 3: Activity frequency of low and highstatus students and its percentage distribution during group work. (by Author)

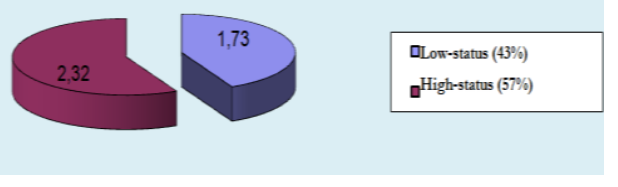

In contrast, in the control group, the activity rate of low-status children is 0.08 in 3 minutes while that of high-status children is 0.23 , so the difference is 2.9fold (Figure 4). Comparing the results, we can state that the activity rate of lowstatus students is lower in all comparisons than that of high-status ones. Furthermore, it can also be stated that both low- and high-status students have more opportunities to perform activities in the group work organized by KIP.

Noteworthy is the value obtained in the control classes that performed traditional classroom activities, which indicates that traditional classwork, - similarly to talk activity -, is more favorable for highstatus students to perform activities than for low-status ones although both groups have lower activity rates than during group work.

Figure 4: Activity frequency of low and highstatus students and its percentage distribution during frontal classwork. (by Author)

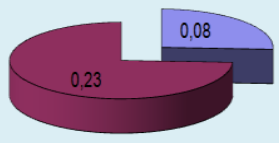

पLow-status (26\%) $\mathbf{0}^{\text {High-status (74\%) }}$

From the frequency of classroom activities of low and high-status students, we conclude that, although higher status students take the opportunity to perform activities in the classroom more often than low-status ones, group work-based work organization provides - similarly to talk frequency - more opportunities for low-status students to develop their activities, to acquire knowledge through experience than traditional classwork, and at the same time, to reduce the gap between students of different status. 


\section{Summary of observations}

While examining classroom work, we used individual student observation sheets to measure certain students' frequency of talk and activity. While carrying out our measurements, we sought to determine whether the use of group work provides opportunities for students to improve their performance, with special attention to low-status ones.

We state that the frequency of talk and task-related activities of students from disadvantaged backgrounds, primarily that of Roma ones, is significantly influenced by the classroom organization chosen by the teacher. While implementing the Complex Instruction Program, we should give particular importance to developing communicative competence in the development of communication skills, as the student who has no language difficulties becomes more successful in learning. Improving communicative competence is a challenge for students from under-socialized backgrounds who have a vocabulary size inferior to that of their community. The most effective way to develop them is to get the student to talk while they act. If we accept that the more the learner talks related to the curriculum, the more he or she learns, and on the basis of the measurements, it can be proved that with respect to knowledge acquisition, lesson organization involving group work is more favorable for lowstatus children than frontal classroom teaching. As they talk more, they are likely not only to acquire more knowledge but to deepen it as well.

We also see that the difference between low and high-status students in terms of talk frequency is reduced during group work, with both groups communicating more frequently than during frontal classwork. This suggests that, in order to increase the performance of lower status students, it is important for the teacher to use a wide range of teaching methods, thus helping each member of the heterogeneous student group to improve his or her performance. We also see that frontal class work does not provide space for developing the knowledge of lowstatus students, but encourages them to perform significantly more poorly than during group work.

In task-related activities, the two types of work organization (frontal and group) gave similar results for the two status groups. In terms of task-related activities, frontal classwork is less favorable for lowstatus children than for those in the opposite group. Group work can reduce it although it cannot eliminate it. The difference remains noticeable, but the distance between the performances of the two groups is significantly smaller than in frontal classwork.

The question for us is whether the teacher understands the use of group work for this reason or whether he or she uses it as a technique for making classwork more varied. If he or she is familiar with the method and sees the 
results, he or she will increasingly feel the need to use group work at an appropriate rate, which will encourage low-status students to perform in class in the desired way and to get engaged in oral communication and task-related activities. The method can change the performance of under-motivated students from poor social backgrounds who are lagging behind in self-expression. The result of this change is that the performance of low status-, mainly Roma students will approach and reach the desired level.

In accordance with the application requirement of the program based on special group work, as the teacher's leadership activity decreases, a collaboration between students increases during group work, which is shown in the frequency of both the talk and taskrelated activities of students. According to our measurements, teacher leadership entails students' need for teacher instruction, assuming that if the teacher is the only source of information for students, a hierarchy, superiority-inferiority is created during collaboration. We achieved the opposite effect if the children worked within the group without adult help. The Complex Instruction Program meets this latter requirement.

The result shows that during group work in accordance with the program, the teacher is able to promote peer-to-peer interaction within the group by transferring his or her leadership role; i. e. the more he or she withdraws, the more children work together. However, if the teacher is not able to transfer the leadership role, that is, teacher leadership prevails, remains, obviously, both low and high-status children talk less and perform less. This in turn adversely affects the engagement of low-status students. There are other positive effects of using the Complex Instruction Program. During group work, developing social skills provides an opportunity for the teacher to enable students to achieve their goals in a way that should be socially acceptable. Ethical norms and models of action are common in group work, which has a significant motivating effect. The established system of norms accelerates personality development, the development, and consolidation of proper principles and forms of behavior. Students' active participation in work, the use of multiple skills, classroom collaboration, learning from peers, eliminating interpersonal competition, and making similarities and differences recognized are a key to success in work. Success motivates, and motivation is a positive experience, an effective longterm incentive that helps students to avoid failure, fruitlessness, and negative experiences. This is of particular importance for Roma students.

Students' joint activities and cooperation are excellent for community education. We consider it to be a result that due to regular work, students in group work are able to accept, tolerate, and appreciate 
their peers from disadvantaged backgrounds or Roma ones to a greater extent, and therefore this form of work can be used well in classes of different levels of knowledge and socialization. Students serve as role models for each other and their joint work helps them with learning, and therefore group work represents an important step in developing collaboration. During the process, children's behavior is pervaded by the behavior of the group, which is one of the cornerstones and requirements of group learning. Working together, on the one hand, provides students with experience and, on the other hand, it gives them the opportunity to gain experience that will facilitate their future integration into society.

One implication of the program is that students at the top of the status ranking benefit from the positive effects of the method as much as the examined group from disadvantaged backgrounds. In addition to increasing their selfconfidence and knowledge through group work, they have the opportunity to practice the norms of behavior and roles that they will practice as adult members of society - and possibly as leaders.

The Complex Instruction Program is a well-considered method based on a broad theoretical foundation and tried out in practice. Perceiving the economic and social changes, the School Community of Hejőkeresztúr decided to use this special cooperative teaching method in the long term as a key tool to help children from disadvantaged backgrounds to catch up, develop talent, establish norms for collaborative work, and develop skills hidden beneath the surface right from the moment they start school.

\section{References}

Cohen, E. G. (1994). Restructuring the classroom: conditions for productive small groups. Review of Educational Research. doi: $\underline{10.3102 / 00346543064001001}$

Cohen, E. G. \& Lotan, R. A. (2014). Designing group work: Strategies for heterogeneous classrooms. Teachers College Press - Columbia University. New York - London.

K. Nagy, E. (2012). Több mint csoportmunka. [More than Group Work]. Nemzeti Tankönyvkiadó.

K. Nagy, E. (2015). KIP Könyv I-II. [KIP Book I-II]. Miskolci Egyetemi Kiadó

K. Nagy, E. \& Révész, L. (2019): Differenciált Fejlesztés Heterogén Tanulócsoportban - DFHT metódus, mint a Komplex Alapprogram tanitási-tanulási stratégiája, fókusz̧an a tanulók statuskezelése. [Differentiated Development in a Heterogeneous Group of Students - DFHT Method as a Teaching and Learning Strategy for the Complex Core Program, with Focus on Student Status Management]. Líceum Kiadó, Eger. 
Mérei, F. (2001). Közösségek rejtett hálózata.

[A Hidden Network of Communities]. Osiris Kiadó, Budapest.

Reményi, A. Á. (1997). Munkahelyi csoportok megszólitási rendszerének szocioling- visætikai viæsgálata című disszertáció [A Dissertation entitled Sociolinguistic Analysis of the Addressing System of Workplace Groups], ELTE. Angol Alkalmazott Nyelvészeti Tanszék.

\section{Appendix}

Individual student observation sheet for frontal class work

Student:

Class:

Teacher:

Status:

Observer:

\begin{tabular}{|l|l|l|l|l|l|l|l|}
\hline \multirow{2}{*}{ Aspect of observation } & \multicolumn{2}{c|}{ 1st minute } & \multicolumn{2}{c|}{ 2nd minute } & \multicolumn{2}{c|}{ 3rd minute } \\
\cline { 2 - 7 } & sec. 1-30 & sec. 31-60 & sec. 1-30 & sec. 31-60 & sec. 1-30 & sec. 31-60 \\
\hline Talk & & & & & & \\
\hline Task-related talk & & & & & & \\
\hline Non-task related talk & & & & & & \\
\hline Behaviour & & & & & \\
\hline Performs independent work & & & & & & \\
\hline Listens & & & & & & \\
\hline Waits for an adult & & & & & & & \\
\hline
\end{tabular}

